IJLRES - International Journal on Language, Research and Education Studies

ISSN: 2580-6777 (p); 2580-6785 (e)

DOI: 10.30575/2017/IJLRES-2018091211

Vol. 2, No. 3, 2018

Page: $436-447$

\title{
THE EVALUATION OF EDUCATION IN THE BOOK OF SAḤIḤ AL-BUKHĀRĪ
} AND SAḤIḤ MUSLIM

\author{
Musriaparto \\ The College for Islamic Studies of Hamzah Fansuri Subulussalam, \\ Nangroe Aceh Darussalam \\ musriaparto@gmail.com \\ Nawir Yuslem \\ Professor in School of Postgraduate \\ The State Islamic University of North Sumatra, Indonesia \\ nawiryuslem@uinsu.ac.id \\ Syamsu Nahar \\ School of Postgraduate, The State Islamic University of North Sumatra, Indonesia \\ syamsunahar@uinsu.ac.id
}

\begin{abstract}
This study aims to delve deeper into the evaluation of education, especially Islamic education, contained in the traditions of the Prophet Muhammad SAW which is narrated in two major books, namely the Book of Sahih Bukhori and Sahih Muslim. This research was conducted by classifying the hadiths in the two books into groups of hadith indicated as hadiths about the evaluation of education. As a finding, there are three terms in the two major hadith books, namely Al-Hisab, Al-Bala ', and Al-Imtihan. In the Saheeh Bukhari and Saheeh Muslim books the traditions of the evangelization of education are clearly explained. so that it can be concluded that Islamic Education related to evaluation has been clearly described through the Prophet's hadiths narrated in the books of Sahih Bukhari and Sahih Muslim.
\end{abstract}

Keywords: The Evaluation of Education, Shahih Bukhari, Shahih Muslim

\section{INTRODUCTION}

Islamic education is an education based on the values of Islamic teachings as stated in the Qur'an and al-Hadith and in the thoughts of the Islamic scholars. In the process, Islamic edu cation makes the goal as an ideal aims to be achieved. The ușuliyah adagium states that: "Al-Umūr bi maquașidihā", means that every action and activity must be oriented to a set goal or plan, to find out the achievement of an activity goal, namely evaluation. 


\section{The Evaluation of Education in the Book of Saḥiḥ Al-Bukhārī and Saḥiḥ Muslim DOI: 10.30575/2017/IJLRES-2018091211}

To find out the achievement of learning objectives or competencies expected by students, can be known through evaluation. In other words, evaluation is used as a tool to determine whether an educational goal has been achieved or not. In Islamic education, evaluation is one component of the education system that must be carried out systematically and planned as a tool to measure the success or targets to be achieved in the process of education and learning.

Many traditions have described evaluation in educating people to be better. Rasulullah SAW carried out an evaluation directly by evaluating by testing the friends, if it had not reached the expected size, the Prophet Muhammad emphasized and added material, in the form of advice, direction and so on.

Based on the description above, it can be concluded that evaluation in the Islamic tradition especially in educating human beings has existed and is well established conceptually, but so far there has not been any in-depth research and discussion about the concept of evaluating education in Islam so that the authors feel interested in seeing the evaluation Rasulullah SAW in educating humans by referring to the traditions of the Prophet Muhammad.

\section{LETERATURE REVIEW}

\section{The Position of Evaluation of Islamic Education}

Educational evaluation has a very strategic position, because the results of evaluation activities can be used as input to make improvements in learning activities. Islamic teachings also pay great attention to evaluation. Allah SWT. said in the Quran which tells us, that evaluation of humans is an important task in the series of educational processes that must be carried out by educators. This is in accordance with the word of Allah SWT. below:

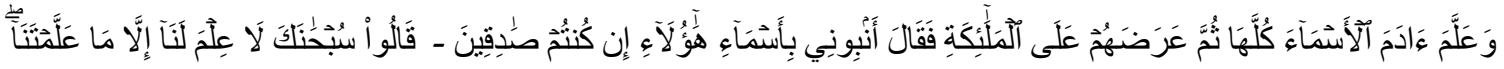

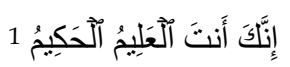

Meaning: And He taught Adam the names (objects) entirely, then presented them to the angels, then Allah SWT. said: 'Name me the things if you are truly righteous. They answered, "Glory to You, there is nothing we know but what you have taught us, surely you are the Knower, the Wise

From the above verse some conclusions can be drawn. First, Allah SWT. In the

${ }^{1}$ QS. al-Baqarah [2]: 31-32. 
verse acts as a teacher who gives lessons to Prophet Adam. Second, the angels because they did not get a lesson from Allah SWT. As received by Prophet Adam, they could not name the objects that had been given to the Prophet Adam. Third, Allah SWT has asked the Prophet Adam to demonstrate the teachings he had received before the angels. Fourth, the verse implies that the material to be tested (evaluated) must be the material that has been taught.

\section{The Terms of Evaluation of Islamic Education}

Terms that can be used in Islamic evaluations are as follows:

a. Validity, which is an evaluation carried out based on the things that should be evaluated, covering all specific fields desired and investigated. So that it does not only cover one field, test questions must give a representative (overall) description of the child's ability to do so.

b. Reliable, that is, evaluations that must be trusted, namely providing accuracy with information about the true abilities of students, the questions displayed do not only carry various interpretations.

c. Efficiency, which is an easy evaluation in the administration, evaluation and interpretation.

\section{The Book of Șahịh al-Bukhārī}

The book Șaḥịh al-Bukhārī is a collection of books (books) of Hadith compiled by Imām al-Bukhārī (full name: Abū Abdullah Muḥammad Ibn Ismāil Ibn Ibrāhīm Ibn al-Mugīrah al-Ja'fari) who lived between 194 and 256 Hijriyah. The full title of this book is al-Jāmi 'al-Musnad al-Șaḥịh al-Mukhtasar min' Umūr Rasūlillahi wa Sunnanihi wa Ayyamihi. Attempting to collect the Șaḥih traditions in his book, Imām al-Bukhārī uses scientific and legal research rules that cause the Șahịh of his traditions to be accountable. He tried earnestly to examine and investigate the circumstances of the narrators of the hadith, and to obtain with certainty the divinity of the traditions narrated. He always compares the narrated traditions, one to the other, filtering them out and choosing which matan according to him is Șahịh. So the book is a benchmark and filter for these traditions. He was also very careful in each gathering, this can be seen from the confession of one of his students named al-Firabri who explained that he heard Muhammad Ibn Ismā'îl al- 


\section{The Evaluation of Education in the Book of Saḥiḥ Al-Bukhārī and Saḥiḥ Muslim DOI: 10.30575/2017/IJLRES-2018091211}

Bukhārī said: "I compiled the book of al-Jamī 'al-Ṣaḥị̣ in the Grand Mosque, and I did not include even a hadith, except after I prayed for two rak'ahs and begged Allah. First and after that, then I believe that the hadith is truly valid.

The purpose of the statement is that Imām al-Bukhārī began to compile his chapters and the basics in the Haram in a systematic manner, then wrote the introduction and the subjects in Raudah the place between the tomb of the Prophet. The pulpit of the Nabawī Mosque. After that, he collected the traditions and placed them in the appropriate chapters. This work was carried out in Mecca and Medina diligently and meticulously, compiling it for 16 years, every time he wanted to write a hadith, he took a bath and did istikhärah. ${ }^{2}$ The effort, making the book as the most complete, and its value is not found in other books. Therefore, it is not surprising that the book has a high position in the hearts of the scholars and has become the agreement of scholars and Muslims that the book Șahị ị al-Bukhārī is the most authentic book of hadith and occupies a place of honor after the Qur'an. ${ }^{3}$

\section{The Book of Șahīh Muslim}

The book Șahị Muslim is a collection of hadith books compiled by Muslim Imām. This book of Șahịh Muslim according to Hasbi as-Siddiqie is the second book after al-Jāmi 'al-Ṣaḥị̣ by Imam al-Bukhārī which is a guide and guideline. In terms of composition, the book of hahạịh Muslim is more systematic than Șahịị al-Bukhārī, hence it is easier to search for hadith in it than to search for hadith in the book Ṣahīh al-Bukhārī. Muslim Imām places traditions about ablution, for example in the ablution section, not scattered here and there like the book ȘaṢịh al-Bukhārī. The full title of the book Șahị̣̂ Muslim is al-Musnad al-ḥahịḥ al Mukhtasar min al-Sunān bi Naql al-'Adl 'an al-'Adl' an Rasul of Allah. ${ }^{4}$

In the book Șahịh Muslim, the traditions and routes of transmission are presented to the reader with orderly and beautiful arrangement and presentation. That beauty can be found from the Muslim Imām taḥīiq who are mature towards the path of the narration of the hadith, so that the substance of the book is very deep and full of various

${ }^{2}$ T.M. Hasbi Ash-Shiddieqy, Sejarah dan Pengantar Ilmu Hadis, Cet.VI (Jakarta: Bulan Bintang, 1980), h.106.

${ }^{3}$ Nawir Yuslem, Sembilan Kitab Induk Hadis Biografi Penulisnya \& Sistematika Penyusunannya, Cet.I (Jakarta: Hijri Pustaka Utama,2006), h.55.

${ }^{4}$ Nawir Yuslem, Ulumul Hadis..., h. 480. 
forms of authority and prudence. The slender and concise pattern of the presentation of the hadith is carried out after Muslim Imām corrects the narration of hadith by selecting and limiting the meaning of the hadith so that it is not too broad. Muslim Imām always tries to convey the traditions of the hadith as received from his teacher without breaking history and not narrating the hadith with their meanings. All traditions in the book of Șahịh Muslim include one discussion, the hadith mentioned in full. This is not like in ḥaḥị̣ al-Bukhārī who mentions one hadith with fragments separately in several chapters according to the chapter. ${ }^{5}$ Editor of the book Sḥahịh Muslim is well arranged, short, solid, slim and clear, the placement of the traditions neatly and arranged based on their meaning. ${ }^{6}$

\section{MEHODOLOGY}

This type of research is a type of library research. Library research is a study that refers to data that is in reference in the form of books / Sahih Bukhari and Sahih Muslim about educational evaluation. The method used in this research is descriptive method. In accordance with the name of this study do not collect interactively through interaction with human data sources. Rather, the researcher collects, identifies, analyzes, and synthesizes data to then provide an interpretation of concepts, policies, events that can be directly or indirectly observed. The data source is documents. The documents referred to by researchers in this study are the books of Saḥi al-Bukhārī and Muslim Sahih, along with their wishes.

This research can be described by the following steps: First, determine the concept to be studied, the researcher in this case sets out to analyze the evaluation of the Apostle's education contained in the Hadith of the Apostles. Second, explore and identify various evaluations of the Apostle's education found in the books of Sahi alBukhārī and Saḥiḥ Muslim. Third, apply an understanding of the evaluation of the apostle's education in the Hadith of the Apostles in the books of Sahi al-Bukhārī and Saḥih Muslim. Fourth, critically analyze the actual use and meaning of the concept under study, namely the evaluation of education applied by the Apostle. This analysis is carried out using the Islamic education science approach using the method of deductive

\footnotetext{
${ }^{5}$ Syaikh Ahmad Farid, 60 Biografi, h. 514-515.

${ }^{6}$ Ibid., h. 521.
} 


\section{The Evaluation of Education in the Book of Saḥiḥ Al-Bukhārī and Saḥiḥ Muslim DOI: 10.30575/2017/IJLRES-2018091211}

reasoning, which uses the way of thinking from general statements and then draws conclusions of a special nature.

\section{FINDINGS AND DISCUSSION}

\section{Hadiths of Educational Evaluation in the Book of ḥaḥịh al-Bukhārī}

\section{Term of $a l-H i s \bar{a} b$ and its Derivation}

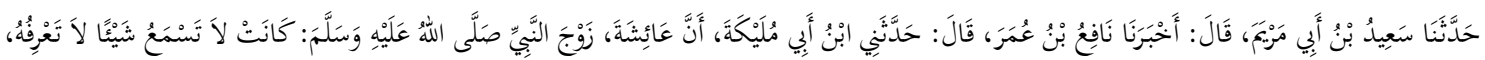

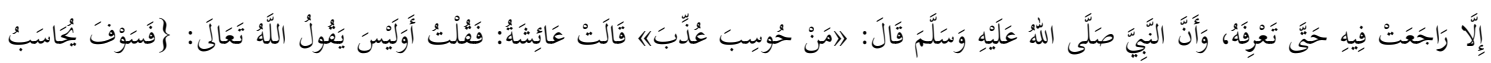

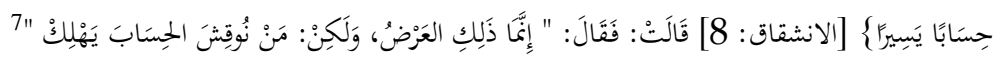

Meaning: Having told us Sa' ìd Ibn Abū Maryam said, having told us Nafi 'Ibn' Umar said, had told me Ibn Abu Mulaikah that Ayesha the wife of the Prophet sallallaahu 'alaihi wasallam had not heard anything that she did not understand except asking the Prophet sallallaahu 'alaihi wasallam until he understood, and the Prophet sallallaahu' alaihi wasallam once said: "Whoever is abused means he is tormented" Aisha said: then I asked the Prophet: "Does not Allah Ta'ala say:" One day he will be humiliated lightly "Ayesha said: Then the Prophet sallallaahu 'alaihi wasallam said:" Indeed what is meant is exposure (practice). But whoever is investigated for reckoning must be harmed ".

The word Hisāb here shows the calculation of charity or evaluation and giving value to the deeds that have been done in the world counted here in order to find out which ones are more good deeds or bad deeds. The purpose of this hadith is that what is calculated by Allah is his charity, he will be subjected to torture even if it is only a little like fear. The lightest calculation is to show all the charity before the culprit. This makes a person feel ashamed and afraid that the charity is shown this is the lightest torture.

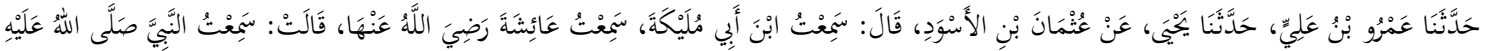

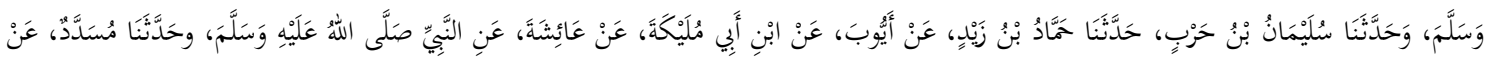

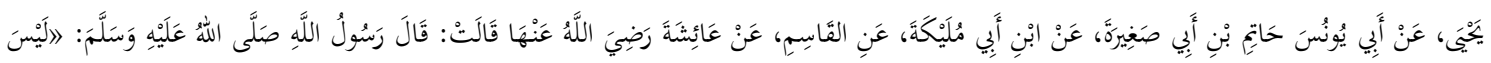

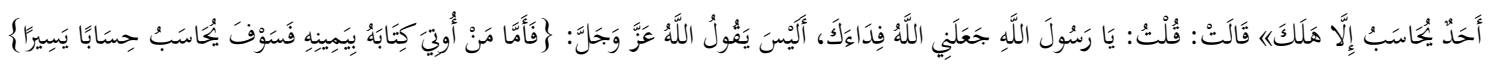

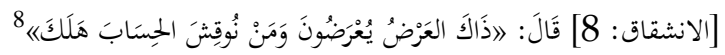

Meaning: From Ayesha radiyallahu 'anha; The Prophet sallallaahu 'alaihi wa sallam said: "There is no one who is rebuked (examined by his deeds) on the Day of Judgment except that

\footnotetext{
${ }^{7} \mathrm{Ab} \overline{1}$ 'Abdillah Muḥammad Ibn Ismā’̄ill al-Bukhari, Șaḥịh al-Bukhārī, Juz. 1, No. 103, 4939, 6536, dan 6537 (Beirut: Dār al-Qalām, 1997), h. 54.

${ }^{8}$ Ibid., Juz. 3, No. 4939, h. 322.
} 
he will perish" Aisha asks: O Messenger of Allah, may Allah be pleased with you. Make me as your advocate, does not God Almighty have said: As for the person given his book from his right hand, he will be examined by an easy examination. [al-Insyiqāq: 7-8] The Prophet sallallaahu 'alaihi wa sallam replied: "That is only limited to the presentation (of his deeds) which is shown to them, but whoever denies the calculation will then perish".

Obviously the term hisāb in the previous traditions means a calculation of charity or auditing one's finances to avoid it from assets that Allah forbid such as bribery or corruption. So the reckoning here can be interpreted by evaluating or giving good and bad values.

\section{Term of al-Bala' and its derivation}

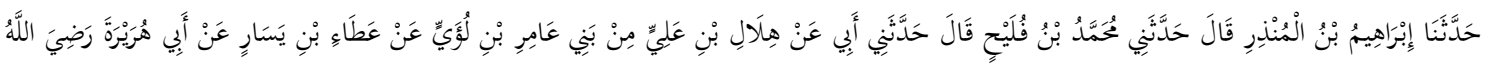

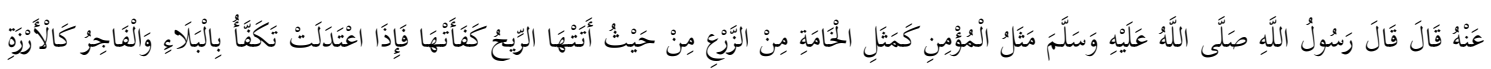

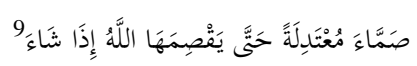

Meaning: Having told us Ibrähìm Ibn Mundzìr he said; had told me Muhammad Ibn Fulaih he said; had told me my father from Hiläl Ibn Ali, a resident of Bani 'Amir Ibn Lu'ai, from' A 'a 'Ibn Yasar of Abü Hurairah radiallāhu' anhu he said, the Messenger of Allah șallallāhu 'alaihi wasallam said: "The example of a believer is like a branch in a tree which can be bent when blown by the wind and when it is struck by calamity he will remain upright, while the example of the fajir is like a rice plant that is always upright so that Allah SWT will knock it down whenever he wants".

The word bala here is a test with something bad happening to someone to find out whether he is patient or not. If he is patient then he can be judged well and if not then he is called a bad servant.

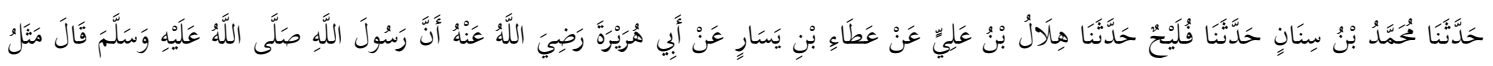

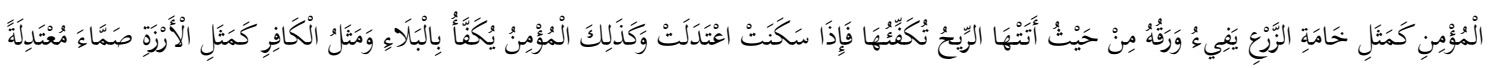

$$
\begin{aligned}
& \text { حَتَّى يَقْصِمَهَا اللٌَُّ إِذَا شَاءَ10 }
\end{aligned}
$$

Meaning: Having told us Muhammad Ibn Sinan had told us Fulaih had told us Hiläl Ibn 'Ali of Ața 'Ibn Yasar of Abu Hurairah radiyallahu'anhu, that the Messenger of Allah șallallähu' alaihi wasallam said: "The parable of a believer is like a branch plants whose leaves are tilted according to where the wind comes from, but if they are calm, the branches can return straight. Likewise a believer, sometimes tilted because of an exam. Instead the parable of the infidel is like a straight and hard rice tree, so Allah SWT. (easily) break it anytime you want ".

The tragedy here is also in line with the previous character of this hadith which still has the same theme as before

\footnotetext{
${ }^{9}$ Ibid., Juz. 4, No. 5644, h. 24.

${ }^{10}$ Ibid., Juz. 4, No. 7466, h. 398.
} 


\section{The Evaluation of Education in the Book of Saḥiḥ Al-Bukhārī and Saḥiḥ Muslim \\ DOI: 10.30575/2017/IJLRES-2018091211}

\section{Term of al-Imtihan and its Derivation}

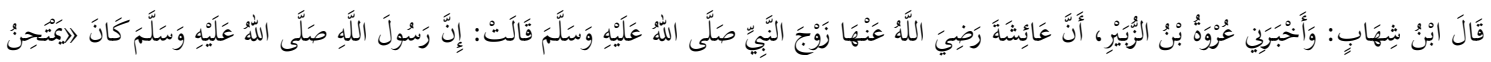

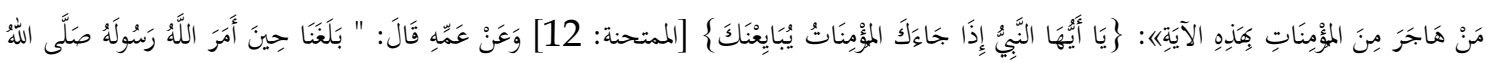

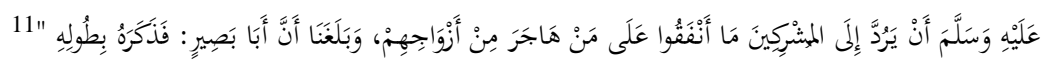

Meaning: Ibn Shihab said; has preached to me 'Urwah Ibn al-Zubair that yah Ayesha radiallāhu' anha, the wife of the Prophet allallallähu 'alaihi wasallam, he said; "The Prophet șallallähu 'alaihi wasallam tested the believing woman who came to emigrate to him based on this verse:" $O$ Prophet, if you come to you women mu' minat to bless you ... "QS Al Mumtahanah: 12. From his uncle said; It has come to us when Allah Ta'ala ordered His Apostle șallallähu 'alaihi wasallam to return to the polytheists what they had given as a living (dowry) to their wives who had emigrated and had come to the news that Abū Bașir. ... "Then he told the full story

The word imtihān here means a test with several commands and prohibitions to know obedience and obedience.

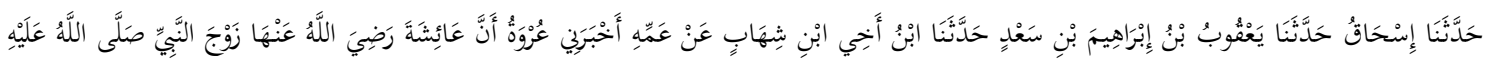

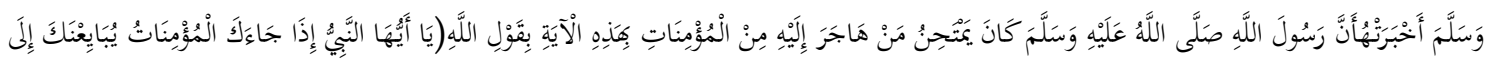

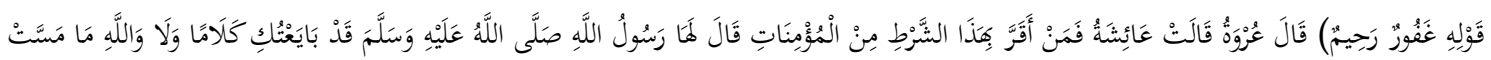

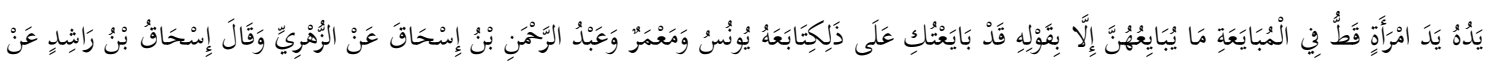

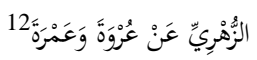

Meaning: Having told us Ishāq has told us Ya'qūb Ibn Ibrāhìm Ibn Sa'dari has told us the son of my brother Ibn Syihāb of his uncle, has preached to me the Urwah of his language Aisha radiallähu 'anha told him, that; The Messenger of Allah allallallähu 'alaihi wasallam tested the women who emigrated to him with this verse: "O Prophet, when the believing women come to me to pay their respects - until His word is (Allah) Forgiving and Merciful too." (QS. Almumtahanah 2). 'Urwah said; 'Aisha said; Believing women who make this requirement, the Messenger of Allah allallallähu 'alaihi wasallam said to him: "Indeed I have blessed you". Namely, he paid his blessings only as an expression and for Allah's sake, his hand never touched the hand of a woman in a ceremony. He never pledged them except by saying: "Indeed, I have blessed you for those words." This hadith is corroborated by Yünus, Ma'mar and 'Abdurrahmān Ibn Ishāq from al-Zuhri and Ishāq Ibn Rashid said; from al-Zuhri from wah Urwah and 'Amrah.

\footnotetext{
${ }^{11}$ Ibid., Juz, 3, No. 4182, h. 132.

${ }^{12}$ Ibid., Juz. 3, No. 4891, h. 307.
} 
This hadith is also in line with the previous one because it has the same theme namely imtihān which means the test with orders and prohibitions to know obedience.

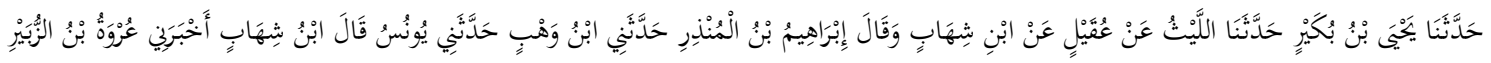

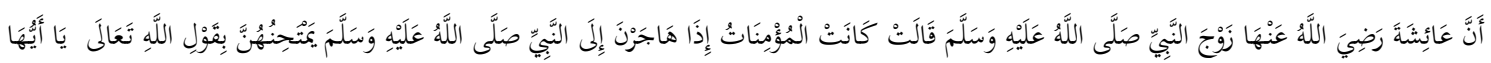

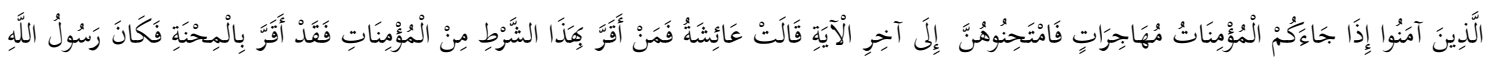

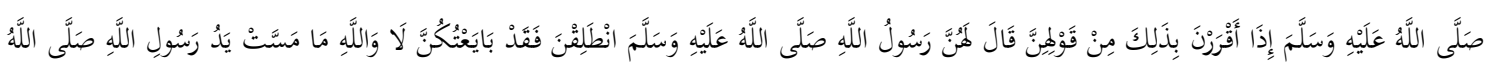

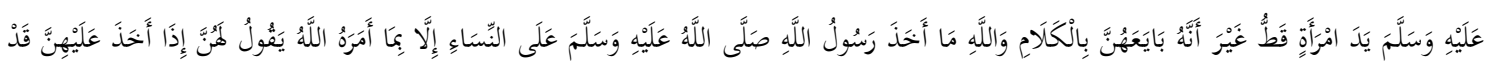

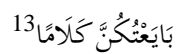

Meaning: Having told us Yahya Ibn Bukair had told us al-Lais from 'Uqail of Ibn Shihab and had said; Ibrāhìm al-Mundzir has told me Ibn Wahab, has told me Yünus, has said Ibn Shihäb, has preached to me 'Urwah Ibn Zubair that yah Aisha radiallähu 'anha the wife of the Prophet șallallähu' alaihi wa salla said; When the Muslim women emigrated to the Prophet allallallāhu 'alaihi wasallam, then he would test them with the word of Allah Ta' ala: "When believing women come to you to emigrate, then test them ..." to the end of the verse (QS. Al-Mumtahanah: 10). Aisha said; Whoever he sets out from the believers with this condition, then he states that he has been tested and is normal if women have made that requirement by their expressions, then the Messenger of Allah allallallähu 'alaihi wasallam will say to them: "Go, verily I have made peace" at you with the expression of pledge. "For the sake of Allah Almighty, it is not the Messenger of Allah allallallähu 'alaihi wasallam to do anything for women except with something that has been commanded by Allah SWT .. If he takes Bai'at from them, then he will say: "I have blessed you with expression of words ".

The conclusion from various traditions about imtihān can be understood to mean the test with orders and prohibitions to know the obedience of one to Allah SWT.

\section{The Hadiths of Evaluation of Education in the Book of Șahịh Muslim}

\section{Term of $a l-H i s a b$ and its Derivation}

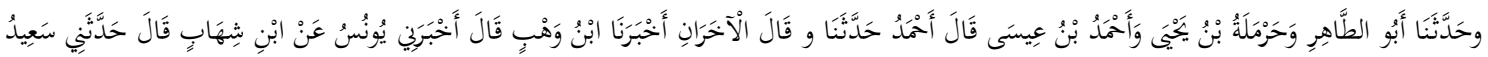

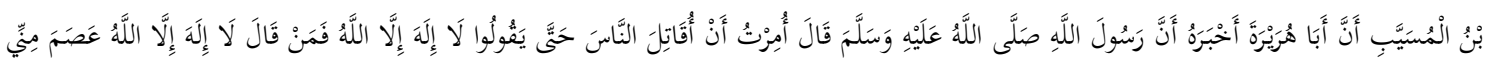

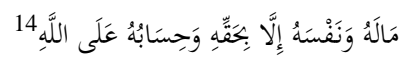

Meaning: And told me Abū al-hirähir and Harmalah Ibn Yahya and Aḥmad Ibn 'Isā, A ḥmad said, told us. Whereas the other two said, having told us Ibn Wahb he said, he had told me Jonah from Ibn Shihab he said, had told me Sa'ìd Ibn al-Musayyāb that Abü Hurairah told him that Rasululläh'allallähu 'alaihi wasallam said: "I was ordered to fight the people until they said, 'There is no God (who has the right to be worshiped) but Allah SWT', then whoever says, 'There

\footnotetext{
${ }^{13}$ Ibid., Juz, 3, No. 5288, h. 409.

${ }^{14}$ Imām Abī Husain Muslim Ibn Hajjāj al-Qusyairy al-Naisābury, Șaḥịh Muslim (Beirut: Dār alKutub al-Ilmiyah, 1412 H /1991 M), Juz, 1, No. 32/20, h. 51.
} 


\section{The Evaluation of Education in the Book of Saḥiḥ Al-Bukhārī and Saḥiḥ Muslim DOI: 10.30575/2017/IJLRES-2018091211}

is no God (who has the right to be worshiped) but Allah SWT.' and his soul from (my attack) except with the rights of Islam, and his reckoning is surrendered to Allah Swt ".

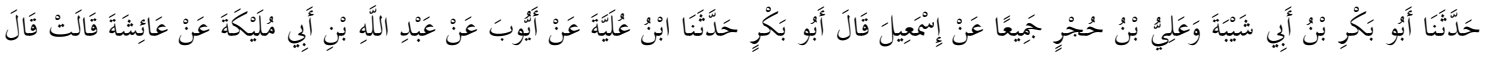

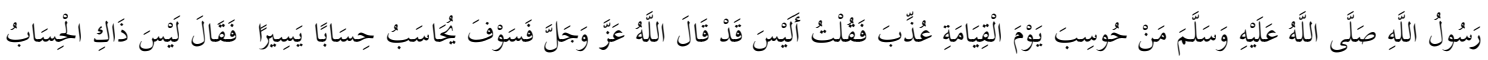

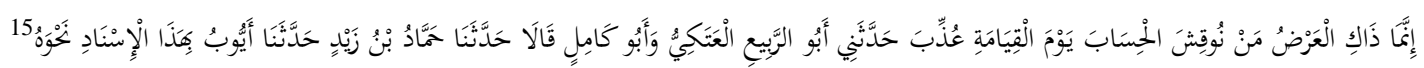

Meaning: Having told us Abū Bakr Ibn Abya Syaibah and 'Alì Ibn Hujr, all from Ismā'il said Abū Bakr, had told us Ibn Ulaiyah of Ayyūb from' Abdullāh Ibn Abū Malikah of 'Aisha said: Rasulullah șallallähu' alaihi wasallam said: "Whoever is taken away on the Day of Judgment, he is tortured". I said: Didn't Allah 'azza wajalla say: "Then he will be examined by an easy examination." (Al Insyiqāq: 8). He replied: "That is not reckoning, it is only explanation. Whoever is denied (when) judgment on the Day of Judgment, he is tortured". Having told me Abū al-Rabi 'al-Ataki and Abü Kämil both said: Having told us Hammad Ibn Zaid had told us Ayyüb with this sanad with a similar matan.

The word Hisāb in the traditions narrated by Muslims here also means what is contained in the hadiths - Hadith al-Bukhār, which is the calculation of good and bad deeds to know obedience.

\section{Term of al-Bala' and its Derivation}

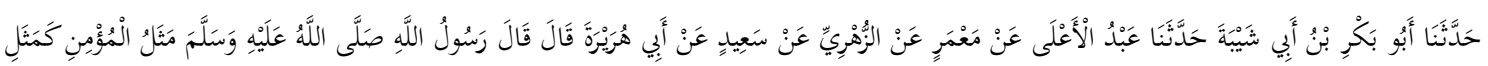

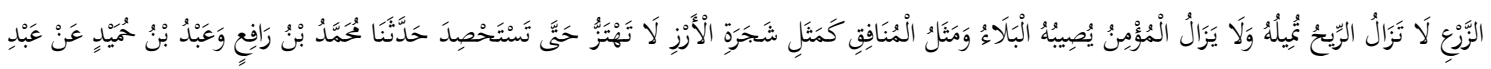

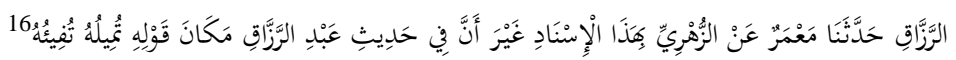

Meaning: Having told us Abū Bakr Ibn Abu Syaibah had told us 'Abd A'la from Ma'mar from al-Zuhri from Sa'id from Abü Hurairah said: The Messenger of Allah șallallähu' alaihi wasallam said: "The parable of the mu'min like plants, the wind always hits him and the mu'min will always be hit by calamities, while the parable of the hypocrite is like a cedar, it doesn't move until it is knocked. " Has told us Muhammad Ibn Rafi 'and' Abd Ibn aidumaid of 'Abd al-Razzaq had told us Ma'mar from al-Zuhri with this sanad, only in the hadith 'Abdu al-Razzaq called the TUFI'UHU instead of TIM gantiLUHU.

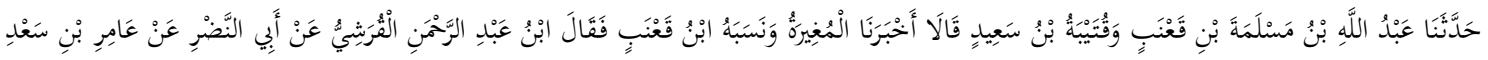

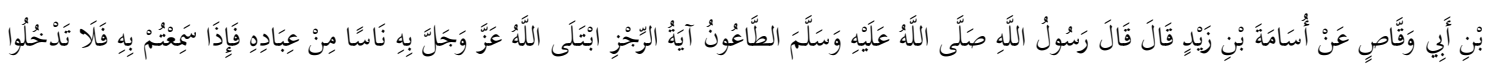

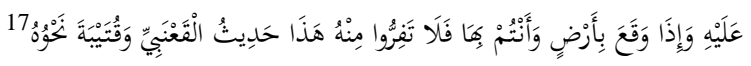

Meaning: Having told us' Abdulläh Ibn Maslamah Ibn Qa'nab and Qutaibah Ibn Sa'ìd both said; It has been reported to us al-Mugir and he is talking to Ibn Qa'nab. Ibn 'Abd al-Rahmān al Quraish said; from Abū al-Naḍr from 'Amir Ibn Sa'd Ibn Abū Waqqash from Usāmah Ibn Zaid

\footnotetext{
${ }^{15}$ Ibid., Juz, 1, No. 79/2876, h. 2204.

${ }^{16}$ Ibid., Juz. 2, No. 2809, h. 2163.

${ }^{17}$ Ibid., Juz. 2, No. 2218, h. 1738.
} 
he said; The Messenger of Allah huallallāhu 'alaihi wasallam said: "Ṭ' un (infectious disease / cholera epidemic) is a warning from Allah Subhānahu Wa Ta' ala to test His servants from among the people. Then when you hear the disease spreads in a country, do not enter the land. If the plague spreads in the land where you are, do not you also run away from it ".

\section{Term of al-Imtihān and its Derivation}

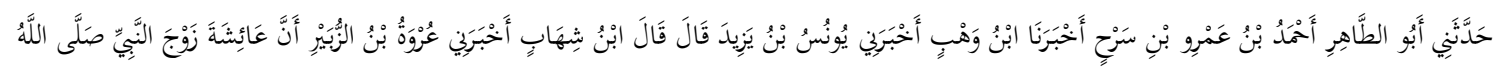

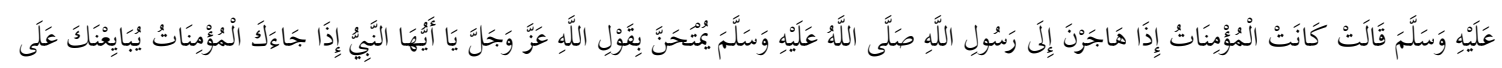

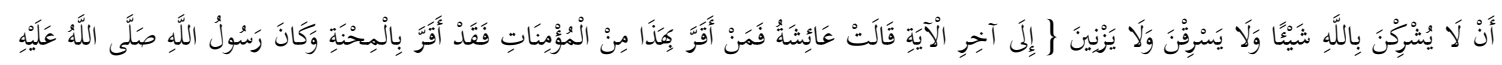

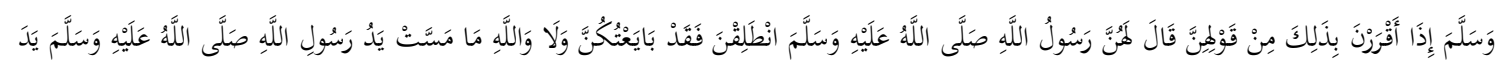

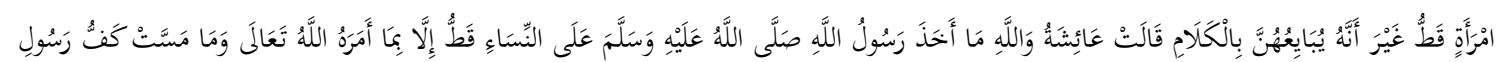

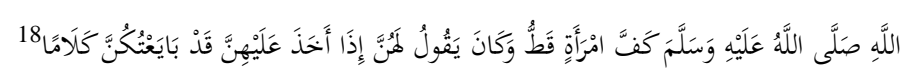

Meaning: Having told me Abū al-Tähir Ahmad Ibn 'Amru Ibn Sarh had told us Ibn Wahb had told me Yünus Ibn Yazìd he said; Ibn Shihab said; has preached to me 'Urwah Ibn al-Zubair that' Ayesha the wife of the Prophet allallallāhu 'alaihi wasallam, asked, "If the believing women migrate to the Messenger of Allah allallallahn' alaihi wasallam, they are always tested as in the word Allah zzazza wajalla: '(O Prophet If the believing women come to make a "faithful promise, that they will not associate with Allah SWT, they will not steal, they will not commit adultery ...)" (Surat Mumtahanah: 12) 'Aisha said, "Who holds steadfastly those promises faithfully, meaning they pass the test, and if they have broken the promise with their words before the Messenger of Allah allallallāhu 'alaihi wasallam, then the Messenger of Allah șallallāhu' alaihi wasallam said to them: "Go, indeed you have paid alms to me. " For the sake of Allah Almighty, the Messenger of Allah allallallähu 'alaihi wasallam never held the hand of a woman, he pledged them with words. 'Aisha continued, "By Allah Almighty, the Prophet allallallähu' alaihi wasallam never took an oath to women except for what was commanded by Allah, and he never touched the palm of a woman, if he paid them a favor, he just say: "Surely I have blessed you."

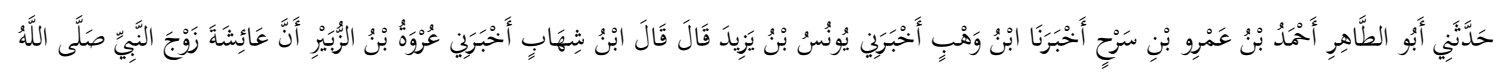

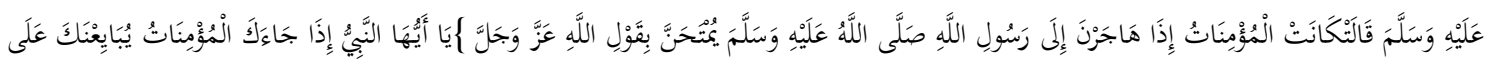

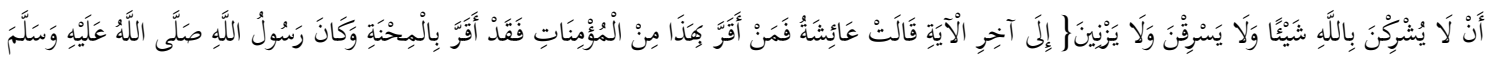

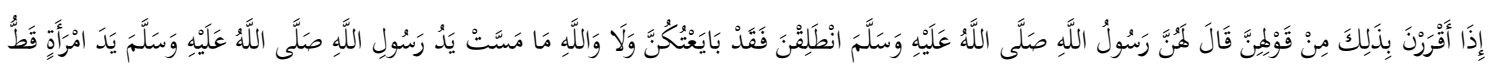

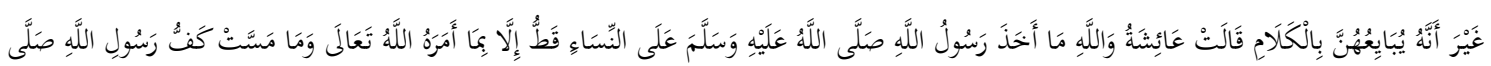

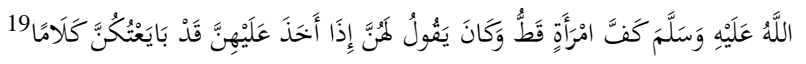

Meaning: Having told me Abū al-Ṭāhir Ahmad Ibn 'Amru Ibn Sarh had told us Ibn Wahb had told me Yünus Ibn Yazìd he said; Ibn Shihab said; has preached to me 'Urwah Ibn al-Zubair that' Ayesha the wife of the Prophet allallallähu 'alaihi wasallam, asked, "If the believing women

${ }^{18}$ Ibid., Juz, 4, No. 1866, h. 1489.
${ }^{19}$ Ibid., Juz. 3, No. 1866, h. 1489. 


\section{The Evaluation of Education in the Book of Saḥiḥ Al-Bukhārī and Saḥiḥ Muslim DOI: 10.30575/2017/IJLRES-2018091211}

migrate to the Messenger of Allah allallallähu' alaihi wasallam, they are always tested as in the word of Allah zzazza wajalla: '(O Prophet When the believing women come to make a "faithful promise, that they will not associate with Allah, they will not steal, they will not commit adultery ...)" (Surat Mumtahanah: 12) 'Aisha said, "Who holds fast on promises -The promise is faithful, meaning that they pass the test, and if they have broken the promise with their words before the Messenger of Allah allallallāhu 'alaihi wasallam, then the Messenger of Allah șallallähu' alaihi wasallam said to them: "Go, indeed you have blessed me " For the sake of Allah Almighty, the Messenger of Allah allallallahhu 'alaihi wasallam never took the hand of a woman, he pledged them with words. 'Aisha continued, "By Allah Almighty, the Prophet allallallāhu' alaihi wasallam never took an oath to women except for what was commanded by Allah, and he never touched the palm of a woman, if he paid them a favor, he just say: "Surely I have blessed you".

The word imtihān in the traditions narrated by Muslims here also means what is contained in the hadith - the tradition of al-Bukhär, which is a test of command and is forbidden to know the obedience of a servant to Allah Swt.

\section{CONCLUSION}

Educational evaluation is part of the learning strategy that is seen from social learning theory (social learning theory) is a part of reinforcement strategy that has the aim to foster expected attitudes and abilities, such as high work ethic, discipline, and continuous learning. Therefore, the evaluation model must be comprehensive, continuous, and objective. Comprehensive evaluation means to assess various abilities such as dimensions of perseverance, thoroughness, discipline in learning, time discipline, self-discipline, independence, democratic attitude, sense of responsibility, and honesty, not as long as only assessing cognitive abilities. Continuously meaningful evaluation that targets all dimensions of learning as a civilizing process if carried out continuously without being perceived as a burden but as a means to increase motivation and without the attitude expected to be formed as part of efforts to achieve national education goals. Objective means that the evaluation has no bias and there is no negotiation in giving an assessment.

\section{BIBILIOGRAPHY}

Al-Bukhari, A, A, M. (1997), Șaḥị̣ al-Bukhārī, Dār al-Qalām, Beirut

Al-Naisābury, A, M, A. (1991), Șahịḥ Muslim, Dār al-Kutub al-Ilmiyah, Beirut.

Ash-Shiddieqy, H. (1980), Sejarah dan Pengantar Ilmu Hadis, Bulan Bintang, Jakarta

Yuslem, N. (2006), Sembilan Kitab Induk Hadis Biografi Penulisnya \& Sistematika Penyusunannya, Hijri Pustaka, Utama Jakarta. 